\title{
BONDING SOCIAL CAPITAL IN ENTREPRENEURIAL DEVELOPING COMMUNITIES - SURVIVAL NETWORKS OR BARRIERS?
}

\author{
By Yael Levitte
}

\begin{abstract}
This paper focuses on the interaction between social capital and entrepreneurship in Aboriginal communities in Canada. Using statistical and interview data from three First Nations communities in northern Ontario, I examine if and how bonding networks turn into tangible resources for business development. The paper also highlights ways in which community relationships hinder entrepreneurship and turn into barriers to economic development. The paper concludes with examples of how insight into the interaction between public policy and social networks can help understand the barriers and opportunities facing community developers in marginalized communities around the world.
\end{abstract}

Keywords: economic development, entrepreneurship, social capital

\section{INTRODUCTION}

The twentieth century was marked by a lively debate about the importance of social institutions to economic exchange. From Simmel (1971 [1908]), Weber (1969 [1920]) and Polanyi (1957) to Granovetter (1973; 1985), Putnam (1993; 1995), Portes \& Landolt (1996) and Woolcock (1998), there is wide agreement that social relations can turn into both resources and liabilities for economic development, and especially for entrepreneurship. This paper focuses on one specific concept, social capital, to explore the question of whether various social relations are an asset or a liability for entrepreneurial activity.

The analysis is based on research conducted in three Aboriginal ${ }^{1}$ communities in northern Ontario, Canada. Two centuries of radical transformations in the ways of life of Aboriginal peoples in North America have resulted in great social upheaval, documented by substantial research (e.g., Hawthorn, Cairns et al., 1966; Shkilnyk, 1985; York, 1990; Gagnè, 1994; Royal Commission on Aboriginal Peoples [RCAP], 1996a; Warry, 1998; Abadian, 1999). Stimulating Aboriginal economies is key to the improvement of Native peoples' lives. The majority of policies designed to stimulate economic development in First Nation communities in Canada has been geared towards entrepreneurship, since individual economic success is assumed to strengthen the community (by generating jobs and wealth). Moreover, the community as a collective is perceived as a potential entrepreneur, providing employment for members and generating capital for social and economic programming.

Yael Levitte is a Visiting Assistant Professor at the Department of City and Regional Planning, Cornell University, 307 W. Sibley, Ithaca, NY, 14853. Tel: 607-254-6545. Email: yl343@ cornell.edu 
Much of the research on Aboriginal business development has emphasized the challenges facing Aboriginal entrepreneurs, specifically those related to access to markets, skills, capital, and resources. This body of research is gradually shifting towards exploring soft, institutional explanatory factors, such as community structure, culture, and governance, to understand variations in Aboriginal economic development (for examples, see Cornell \& Kalt, 1991; 1992). Interestingly, social capital, a concept that has gained much attention in the past decade, has rarely been discussed in relation to Native business development. The findings in this paper point towards important links between social networks and social capital and successful Native entrepreneurship.

The relationship between social capital and entrepreneurship has been more widely explored in contexts other than the Native one (for examples, see Portes \& Landolt, 2000, and a discussion below). In this growing body of research, scholars highlight findings that show the ability of social networks to pull together financial and other material resources for business development on the one hand, and to apply pressures on entrepreneurs on the other. The analysis presented here highlights the importance of social networks in overcoming less explored challenges to entrepreneurship, such as access to training, access to markets, and the negotiation of community values and norms.

In the remainder of this paper I first review the literature on social capital and its links to entrepreneurship. Next, I provide a brief description of the communities and the methodology used in this project. I also identify key social capital factors that helped or hindered community and individual businesses in the participating communities. Finally, I present findings and policy implications, highlighting a number of considerations that policy makers can include as they devise funding programs and marketing plans for new businesses.

\section{SOCIAL CAPITAL AND ECONOMIC DEVELOPMENT: THE CASE OF ENTREPRENEURSHIP}

Social scientists agree that geographical, cultural, and social variables are important to an understanding of economic life (e.g. Granovetter, 1985; Light \& Karageorgis, 1994; Martin, 1994; Gertler, 1995; Leyshon \& Thrift, 1997; Gertler, 2003); some point to the ability of communities, firms and organizations situated within ethnic enclaves (e.g., Light \& Bonacich, 1988; Light \& Karageorgis, 1994; $\mathrm{Li}, 1998$ ) or embedded in geographically-bounded areas (Putnam, Leonardi \& Nanetti, 1993; Gertler, 1995; 1997; Storper, 1997; Porter, 1998; Barnes \& Gertler, 1999) to support and promote their members' economic success. Others point at barriers, and in particular at the exclusion of certain groups from economic life (e.g. de Haan \& Maxwell, 1998; Evans, 1998; Gaventa, 1998).

The last decade has seen the meteoric rise of one concept in particular social capital. The concept, defined here as networks and relationships, which are imbued with values, norms, and attitudes and that facilitate trust, reciprocity, and the collaborative production of tangible resources like services and money, ${ }^{2}$ has taken center stage in the debate over the significance of the 'social' and the 
'cultural' in the 'economic.' ${ }^{3}$ Schafft and Brown (2002, p. 2) report that a quick subject search of the on-line Social Sciences Citation Index for articles concerning social capital indicates an increase from two or three citations in the early 1990s to more than 200 articles per year by 2001 (books on the subject are not included in this search).

\section{Individual and Community Social Capital - A Typology}

Individuals and communities use different types of networks for attaining different goals. Granovetter $(1973 ; 1995 a)$ has coined the terms 'strong' and 'weak ties' to describe the various networks and their usefulness. In a study of job-seeking practices, he concluded that job-seekers who reached for referrals beyond networks of family and close friends (i.e., their 'strong ties') into networks of acquaintances (i.e., 'weak ties') fared better in actually landing a position. Briggs (1998) suggests that weak ties provide social leverage and help people 'get ahead,' whereas strong ties offer social support. Individuals with more extensive weak ties are more likely to reach out vertically i.e., upwards (Lin, 1998), while those who have ties that are primarily local may lack connection to the wider world and its more expansive opportunities (Erickson, 1998).

Whereas the studies described above focus on personal networks employed by individuals, a large body of literature addresses social capital in community and institutional settings. Communities, like individuals, can benefit from social relationships by pooling resources and reducing opportunism (Collier, 1998), thereby enabling these groups to deal with the challenges of poverty (Narayan, 1999; Woolcock \& Narayan, 2000). Furthermore, Woolcock (2000) maintains that a defining feature of poor communities is limited access to certain social networks and institutions. Gittell and Vidal (1998) have coined the terms 'bonding' and 'bridging' to describe the different levels of social capital in communities. 'Bonding' refers to relationships between people who know each other well, i.e., family members, close friends, and neighbors (Gittell \& Vidal, 1998; Woolcock, 2000; Woolcock \& Narayan, 2000), which correspond to Granovetter's 'strong ties.' These relationships are often considered the building blocks for relationships with broader social networks. 'Bridging' social capital, corresponding to Granovetter's 'weak ties,' refers to relationships between people who do not know each other well (Gittell \& Vidal, 1998), i.e., associates and colleagues, or people who share some demographic characteristics, irrespective of how well they know one another (Woolcock, 2000).

Although relationships within and between communities and organizations are crucial for collective action and for social and economic change, Woolcock (2000) also stresses the need to foster relationships with formal institutions beyond the community, i.e., 'linking' social capital. Using Briggs' (1998) concept of 'social leverage,' Woolcock asserts that strong relationships with formal institutions are instrumental in that they allow groups to access resources, ideas, and information from institutions of power. Lack of bridging and linking 
networks, on the other hand, can be restrictive to economic development efforts. Evans (1996), for example, believes that the obstacles that poor communities face stem from their members' inability to 'scale up' micro-level social capital and social action to a politically and economically effective level.

\section{Social Capital - Costs, Risks and Concerns}

Politicians and policy makers have embraced social capital theory and have undertaken to devise policies that encourage its incorporation in public policy. Robert Putnam, for example, brought the concept into the White House during Bill Clinton's presidency, and the World Bank has also welcomed the concept into its policy and research division.

The recent use of social capital by policy makers in the public sphere has led to a set of concerns. Some scholars have argued that social capital can be used to justify contradictory policies, especially for poor societies. Both Woolcock (1998) and Rankin (2002) observe that conservatives invoke social capital to justify increased reliance on voluntary support groups and the dismantling of the welfare state. Woolcock notes, however, that liberals also regard social capital as a tool to correct market failures, and to ensure that the rule of law and due process applies to everyone.

Another concern with social capital research is that, by overusing the term, one risks "trying to explain too much with too little" (Woolcock, 1998, p. 155). Gertler (2000), on the other hand, contends that in some cases exactly the opposite occurs, i.e., that current social capital analysis is incomplete, and does not explain, for example, "why some regions or nations appear to have an abundance of social capital while others have little" (p. 747). The use of social capital in public policy can also result in misguided planning strategies (Portes \& Landolt, 1996). Portes and Landolt argue that the "call for higher social capital as a solution to the problems of the inner city misdiagnoses the problem" (p. 21). It is not the lack of social capital but the lack of economic stability and opportunities for autonomous growth that underlie the plight of these impoverished neighborhoods (Portes \& Landolt, 1996; 2000).

The debate over the use of social capital as a policy tool is particularly heated around economic development issues. Proponents of the concept celebrate the marriage of the 'social' (relationships and networks) with the 'economic' (resources and money), arguing that the merger of disciplines results in a better understanding of the practices that foster economic growth and stability (e.g., Cooke \& Morgan, 1993; Putnam, 1993; Fukuyama, 1996; Morgan, 1997; Grootaert, 1998). At the same time, researchers agree that one should embrace the conceptual union critically, pointing at the potential costs and risks implicit in social capital, such as nepotism or exclusion of certain ethnic groups from certain occupations and industries, or the imposition of excess claims on group members and restrictions on their individual freedoms (e.g., Portes \& Sensenbrenner, 1993; Portes \& Landolt, 1996; 2000; Portes, 1998; Woolcock, 1998; Adler \& Kwon, 1999). 


\section{Social Capital, Social Networks, and Entrepreneurship}

The potential costs and risks to individual freedoms and excessive restrictions is of special interest to researchers studying firms and entrepreneurs (e.g. Flora et al., 1997; Gertler, 1997; Granovetter, 1995b; Light \& Rosenstein, 1995; Portes $\&$ Landolt, 2000; Swedberg, 2000). These researchers have commented on the specific benefits and costs of bonding and bridging social capital for setting up and expanding local enterprises. Portes and Landolt (2000), for example, describe how community members provide some of the needed resources for budding garment firms in Guatemala's San Pedro:

The expansive social networks that link San Pedro's microentrepreneurs facilitate the flow of a variety of resources. Apprenticeship in the workshops of family, friends, and acquaintances represents the first step in establishing an independent outfit. Financial assistance for starting a workshop is typically given by kin, and once a workshop is established, friends and family in San Pedro refer the new entrepreneur to the international firms with which they have been working. In San Pedro Sacatepequez both altruistic and instrumental sources of social capital facilitate the sharing of knowledge, capital loans, and business contacts with manufacturing firms (, p. 539).

Granovetter highlights how the expectation of members in the solidarity group can lay excessive non-economic demands on the newly formed firms (1995b, p. 137). Such claims, according to Portes and Landolt (1996; 2000), can eventually turn businesses into welfare agencies or simply bankrupt them.

The literature on ethnic entrepreneurship in the United States reaches similar conclusions about the advantages and disadvantages of ethnic networks in business development (e.g., Li, 1998; Light \& Bonacich, 1988; Waldinger, 1986). Summarizing some of this literature, Woolcock observes that "without a strong community group to provide initial financial resources, small businesses fail to get started or go bankrupt in the early stages" (Woolcock, 1998, p. 174). These networks can be too restrictive, however, and therefore Woolcock notes that businesses -

need to forge and maintain linkages transcending their community so that:

(i) the economic and non-economic claims of community members can be resisted when they undermine (or threaten to undermine) the group's economic viability and expansion; (ii) entry to more sophisticated factor and product markets can be secured; and (iii) individuals of superior ability and ambition within the business group itself are able to insert themselves into larger and more complex social networks (p. 175).

Reaching out beyond one's locality to access ideas and markets is not only beneficial for business start-up and expansion, but is essential for firm innovativeness (Grabher, 1993; Gertler \& Levitte, forthcoming). In a forthcoming study, Gertler and Levitte demonstrated that to be innovative and commercially successful, Canadian biotech firms must reach out to both their local and global networks to access both knowledge and capital. Grabher studied the steel industry in the Ruhr region in Germany. He found that strong ties between and within firms 
replaced exchange with external partners and filtered information and perspectives necessary for approaching problem solving and development creatively. Such ties therefore generated a "cognitive lock-in" that isolated individuals, organizations, and communities from the world outside them (Grabher, 1993).

This discussion of social capital and entrepreneurship hints at some of the challenges entrepreneurs, especially those living in marginalized areas, must address: access to capital, the need to innovate, and the demands and expectations of the local communities from business owners. These demands are intensified in remote and rural communities, such as the ones participating in this study. Resources in such communities are often scarce and entrepreneurs rely on their communities to supply both workers and customers.

The social capital and entrepreneurship literature neglects, however, some issues important in marginalized areas. For example, while much has been written about access to capital or claims and expectations of communities from their entrepreneurs, other issues such as access to training, access to markets, or issues related to community values and norms have been less researched. The remainder of the paper will explore the question of whether bonding networks generate resources to overcome such challenges to business development, or whether they exacerbate them.

\section{RESEARCH METHODS}

\section{Communities}

The three case study communities are located in remote areas in Ontario, Canada. Two of the communities are located on an island in northern Ontario (referred to as the northern communities), and are accessible to the highlypopulated, urbanized part of the province only by train or by plane. The car and train trip from southern Ontario is about 380 miles long and takes about 14 hours. The local airport and train station are not located on the island, but in a small town across the river that flows around the island; transportation to the island is by motor canoe in the summer, by winter road (frozen waterways) in the winter (November-April) and by helicopter in the spring (April-May) and fall (October-November), when the ice breaks or freezes. In the summer there is daily train service; in the winter, however, the rail service is reduced to three times a week. The two communities number a total of about 2100 people. Other communities in the area are accessible only by plane in the fall, spring, and summer. In winter one can reach these communities by a winter ice road.

The third community (which will be called the central community) is located on an island in a bay in mid-north Ontario, and is accessible to the highly populated, urbanized part of the province by ferry and by road. Even though the trip by car (about 300 miles) is longer than by boat (about 200 miles), the former journey takes less time because the roads around the bay are better than the roads leading to the ferry. The community has about 1000 members. Other places on the island and the nearby area are car accessible. 
Information about the communities shows that they share both strengths and challenges. Interviewees reported that their communities are peaceful, quiet places, in which they enjoy a sense of closeness and familiarity with other community members, and where they have the benefit of living in a community that is predominantly Aboriginal. The communities were nominated for this study because they are considered by their regional economic development corporation to be economically growing and to have a relatively large number of businesses.

The communities also share many challenges, such as lack of consumer choice (shopping and leisure), dissatisfaction with youth activities, and a struggle with substance abuse. Diabetes and poor health are additional issues that came up in interviews, and reflect a national concern in Aboriginal communities (described in detail in RCAP, 1996b).

\section{Interviewees}

Interviews of 113 individuals (99 individual and group interviews) were conducted. To ensure as varied a sample as possible, I asked to speak with men and women, youth, adults and Elders, and employed and unemployed people, as well as with various stakeholders (see Table 1 for details). Access to communities and interviewees followed RCAP guidelines (1996c).

Table 1. Interviewees' Characteristics

\begin{tabular}{|c|c|c|c|}
\hline & Male & Female & Total \\
\hline \multicolumn{4}{|l|}{ Age } \\
\hline $16-30-$ Youth $^{4}$ & $12(39 \%)$ & $19(61 \%)$ & $31(27 \%)$ \\
\hline $31-55$ & 34 (57\%) & $26(43 \%)$ & $61(53 \%)$ \\
\hline 56 and up - Elder & $10(45 \%)$ & $12(55 \%)$ & $22(20 \%)$ \\
\hline \multicolumn{4}{|l|}{ Employment Status } \\
\hline Employed & 27 (59\%) & $19(41 \%)$ & 46 (41\%) \\
\hline Self Employed & 13 (59\%) & $9(41 \%)$ & $22(20 \%)$ \\
\hline Not Employed & $6(43 \%)$ & $8(57 \%)$ & $14(12 \%)$ \\
\hline $\begin{array}{l}\text { Retired (including retired } \\
\text { persons who sell crafts, }\end{array}$ & & $8(53 \%)$ & $15(13 \%)$ \\
\hline $\begin{array}{l}\text { or practice otner forms of art) } \\
\text { Student (including working }\end{array}$ & $/(4 / \%)$ & $8(53 \%)$ & $15(13 \%)$ \\
\hline summer students) & $3(27 \%)$ & $13(73 \%)$ & $16(14 \%)$ \\
\hline \multicolumn{4}{|l|}{ Accessibility } \\
\hline Train/Plane & 32 (49\%) & $33(51 \%)$ & $65(58 \%)$ \\
\hline Ferry/Road & $24(50 \%)$ & $24(50 \%)$ & $48(42 \%)$ \\
\hline \multicolumn{4}{|l|}{ Role } \\
\hline $\begin{array}{l}\text { Leader } \\
\text { Economic }\end{array}$ & $8(62 \%)$ & $5(38 \%)$ & $13(11 \%)$ \\
\hline development & $9(82 \%)$ & $2(18 \%)$ & $11(10 \%)$ \\
\hline Business person & 15 (56\%) & 12 (44\%) & 27 (24\%) \\
\hline Community member ${ }^{5}$ & $24(47 \%)$ & 38 (53\%) & $62(55 \%)$ \\
\hline Total & 56 (50\%) & 57 (50\%) & $113(100 \%)$ \\
\hline
\end{tabular}




\section{Interviews and Interview Guide}

Local contacts, as well other non-Native scholars, suggested avoiding surveys, since many community members "have been surveyed to death," as one colleague put it. Therefore, I approached this project qualitatively, by conducting in-depth interviews, using an interview guide to help keep the interviews on track, which also resulted in rich data. The interview guide was developed based on a literature review relating to social networks and economic development (e.g., Edwards \& Foley, 1997; Erickson, 1998; Newton, 1997; Woolcock, 1998; 2000), as well as the Social Capital Assessment Tool developed by Krishna and Shrader (1999).

Additional questions that came up in preliminary conversations with staff in regional organizations, such as the Chiefs of Ontario and the Council for the Advancement of Native Development Officers (CANDO), and with researchers and policy makers who have studied Aboriginal Economic Development were included. ${ }^{6}$ A large part of the interview focused on social networks and relationships. Questions addressed issues such as information sharing, types of social and professional organizations that individuals belong to, and ways in which economic development changed or affected community relationships. Questions about relationships between community members and entrepreneurs and among business owners were asked (e.g., with whom do entrepreneurs collaborate? Whom do they compete with? How can community members help or hinder a business? How have businesses changed, if at all, the relationships between entrepreneurs and the community?). Information related to financing sources and government programs was also included. Slightly different sets of questions were devised for different stakeholders, i.e., community member, business owner, leader, and economic development officer. ${ }^{7}$ Each interview took between 45 minutes and 2.5 hours.

\section{FINDINGS: ABORIGINAL ENTREPRENEURSHIP - OPPORTUNITIES AND CHALLENGES}

The most pressing challenges to Native entrepreneurship, based on previous research such as Cornell and Kalt's (1992), Caldwell and Hunt's (1998), and the Native Investment and Trade Association [NITA] (1998) are presented next. For each of these challenges, I explore how bonding networks (family, friends, and community members) help or hinder their alleviation.

\section{Access to Financing and Capital}

One of the most serious barriers to Aboriginal business development is access to start-up and growth financing. According to the RCAP (1996d, p. 890), high levels of unemployment and low income provide few opportunities for individuals to accumulate savings for business investment or to guarantee 
repayment; for the same reasons, family and friends rarely act as loan guarantors. Lending from banks is also rare, as banks deem Aboriginal businesses risky because they are often small and rely on local markets. Moreover, "most Aboriginal communities have no financial institutions. The closest one may be hundreds of miles away, and its staff may have little understanding of, or empathy with, the conditions under which Aboriginal businesses operate" (RCAP, 1996d, p. 908). Finally, even legislation aimed at protecting Aboriginal land and property rights serves as a barrier for financing. Section 89 of the Indian Act reads:

Subject to this Act, the real and personal property of an Indian or a band situated on a reserve is not subject to charge, pledge, mortgage, attachment, levy, seizure, distress or execution in favour or at the instance of any person other than an Indian or a band.

According to this section, those living on reserve cannot use their land or buildings as collateral, so it is often impossible for lending institutions to seize assets if a business fails (RCAP, 1996d, p. 890). These institutions consequently avoid issuing loans to Native entrepreneurs in the first place.

Table 2 describes sources of financing used for business start-ups in the casestudy communities and depicts a somewhat different picture than previous studies: Personal savings are the primary source of business funds in these communities. Local, regional, and federal organizations, however, are a key source of funds as well. The data also show that community-owned businesses are financed mainly by government grants and loans, while individual enterprises rely on personal funds or grants from the band or from the regional Development Corporation.

Table 2. Funding Sources for Business Development

\begin{tabular}{lcc}
\hline & $\mathrm{N}$ & $\%$ \\
\hline Personal funds & 21 & 46 \\
Family & 5 & 11 \\
Regional community development corporation & 13 & 28 \\
Band/Community & 13 & 28 \\
Federal government & 16 & 35 \\
Provincial government & 7 & 15 \\
Bank & 10 & 22 \\
Total & 46 & 100 \\
\hline
\end{tabular}

\section{Daily Business Operations}

Although familial networks seldom support business financing in the casestudy communities, more than half of the entrepreneurs participating in the study rely on family for other forms of assistance, such as watching the business while the owner is away or giving advice. Friends, on the other hand, are not likely to be relied on for such help; although interviewees reported high participation in associational life, such as churches, sports groups, or cultural groups, these relationships did not translate into an exchange of favors in people's professional lives. 
One interviewee claimed that even though there is an attempt in the community to "spread out" jobs, eventually "it's who you know ... You'd get a job if you're related or know someone" (ID6, female, youth). Trust is a key factor in hiring kin for the jobs, since, some interviewees argue, kin would look after their interests, unlike unrelated people.

\section{Access to Skills - Training and Education}

Aboriginal businesses often lack a trained labor force: only one in four Aboriginal entrepreneurs reported having received business training (NITA, 1998, p. 28). Location is an obstacle for better business education; training programs, which are often located near urban centers, require owners to be absent for a long time from the community and from their businesses (RCAP, 1996d, p. 278). In the case study communities, members who chose to move away for education reported being unable to afford the time and money to come back for visits. One woman (ID96, female, adult) described how the distance from her family and friends affected her scholarly achievements:

I remember when I went out to school ... I was so far away from my parents, and I really feel that if they had been closer, or if I had been able to be closer to them or been able to [say] "can I come home for the weekend," I think I would have done so much better.

On the other hand, members who can travel home fare better, especially if they attend school with others from their community: "If they're alone, they don't stick it out. They need support from each other," explains one business woman (ID100, female, adult).

Being away from family is so traumatic that a number of interviewees who have returned to their home community for employment are ready to leave it again, to accompany their children when it is their turn to pursue higher education (ID96, female, adult). Unfortunately, when educated parents leave the community to ensure that the younger generation has the support needed to succeed in higher education, they further deplete the community of a much needed skilled labor force.

\section{Access to Markets and Marketing Strategies}

The human aspect of the challenges to Native entrepreneurship lies not only in the workforce's educational assets, but also in access to customers: most Aboriginal businesses rely on a very small local market. The Aboriginal Businesses Survey (ABS, conducted in 1996 by Statistics Canada) reports that 74 percent of all Aboriginal firms rely on the immediate local market for the majority of their clients. Moreover, nearly three in ten conduct their business with Aboriginal customers only (NITA, 1998, p. 42). Participants in my study also reported that entrepreneurs catered mainly to the local and regional markets: 85 percent reported that they served mainly the close local community. 
Although business people rely on their local networks to sustain them, the data indicate that local residents prefer shopping away from the community. Quality of goods is a key factor in traveling to shop, but the main reason for buying outside the community is the high cost of goods at local stores.

To attract more customers from within and outside the community, businesses market and advertise in the various media available on the islands (e.g., a radio station, newspapers, tourist maps, or websites). In addition to the traditional methods of marketing, some businesses trust that their neighbors will spread the word about them: "the fastest way to access a market [on the island]," one interviewee suggests, "is through word of mouth" (ID 55, male, adult). The data show, however, that word of mouth in a close-knit community can also hinder a business (see Table 3).

All of the study's participants were asked about their social networks' ability to help or hinder businesses in their community. Table 3 shows that the majority of interviewees thought that their bonding networks have the highest potential to be harmful to entrepreneurs by spreading gossip about the business or simply staying away from it.

Rumors and boycotting of a business are often based on tensions between community groups, rather than on the service or goods it provides. When asked about the sources of such tensions, the most common responses were "interfamily tensions," "disagreements about land," and "religion." Interviewees explained that although church and extended family provide community members with information, emotional support and, when possible, tangible resources like employment and money, it is these social units that also divide the community.

In the northern communities, where five churches serve the 2500 residents on the island, about a third of the residents stated that religion is a divisive factor in community relationships. Pentecostals, for example, may avoid businesses owned by Anglicans and vice-versa. The two northern communities are also at odds about land ownership on the small island they occupy (two by three miles). These tensions cause some members to stay away from each other's businesses. Since nearly all businesses rely on the entire island population for their livelihood, animosity between the two communities can translate into economic slowdown, as tensions turn into loss of clients.

Finally, a number of interviewees felt that rumors are often a result of resentment towards successful entrepreneurs. "It's unfortunate," lamented a resident, that "[there is] jealousy towards the more successful people within the community, both business people and [those] with high academic achievements" (ID55, male, adult). At least five individuals asked me whether I was familiar with the "crab theory":

I don't know if you ever heard the story about the crabs, you know, the crabs in the bucket. One crab tries to get out of the bucket and the rest of the crabs are pulling him down, and it's like our First Nations people-some of them have that type of mentality, in terms of advancement and growth (ID91, female, adult). 
Table 3. Who Helps or Hinders Businesses and Why?

\begin{tabular}{lcc}
\hline & $\mathrm{N}$ & $\%$ \\
\hline Can community members help businesses? & 77 & 78 \\
$\quad$ Yes & 16 & 16 \\
$\quad$ No & & \\
How can local community members help businesses? & 67 & 68 \\
$\quad$ Buy and support & 11 & 11 \\
$\quad$ Provide feedback & 6 & 6 \\
$\quad$ Be good employees & & \\
Can local community members hinder businesses? & 74 & 75 \\
$\quad$ Yes & 22 & 22 \\
$\quad$ No & & \\
How can local community members hinder businesses? & 42 & 42 \\
$\quad$ Not support/buy & & \\
$\quad$ Badmouth/gossip 28 28 & 16 & 16 \\
Break in/vandalize & 2 & 2 \\
Unfair competition & &
\end{tabular}

Can members of neighboring communities help businesses?

$\begin{array}{lll}\text { Yes } & 67 & 68 \\ \text { No } & 30 & 30\end{array}$

How can members of neighboring communities help businesses?

Buy and support 43

Work together/spin off businesses $\quad 7 \quad 7$

Provide feedback/advice $\quad 3 \quad 3$

Can neighboring community members hinder businesses?

$\begin{array}{lll}\text { Yes } & 46 & 46 \\ \text { No } & 51 & 52\end{array}$

How can members of neighboring communities hinder businesses?

$\begin{array}{lll}\text { Not support/buy } & 17 & 17\end{array}$

$\begin{array}{lll}\text { Badmouth/gossip } & 7 & 7\end{array}$

$\begin{array}{lrr}\text { Unfair competition } & 15 & 15\end{array}$

Can outsiders/non-natives help businesses?

$\begin{array}{lll}\text { Yes } & 73 & 74\end{array}$

$\begin{array}{lll}\text { No } & 24 & 24\end{array}$

How can outsiders help businesses?

Buy and support

Expert advice

Promote/word of mouth

$46 \quad 46$

44

$11 \quad 11$

Can outsiders hinder businesses?

Yes

$39 \quad 39$

No $\quad 59 \quad 60$

How can outsiders hinder businesses?

$\begin{array}{lll}\text { Not support/buy } & 16 & 16\end{array}$

Badmouth/gossip $\quad 15 \quad 15$

Unfair competition $\quad 10 \quad 10$

Exploit $\quad 6 \quad 6$ 
The RCAP_-(1996d) suggests that the hostility towards achievement and individual effort is often misinterpreted, particularly by outsiders, as a product of Aboriginal emphasis on the collective and the community, when in fact it is part of the experience of individual despair, loss, and low self-esteem (p. 886).

\section{Community Approach to Economic Development: Values and Attitudes}

But even if resentment towards business people is not a product of tensions between conflicting attitudes, disagreements about values that should guide the community in its economic development efforts are a challenge to leaders and entrepreneurs-(see, e.g., Champagne, 1992; Elias, 1995). In the northern communities, people still practice occasional hunting and fishing, and there is often opposition to business ventures that could interfere with these pursuits:

The local people strongly talk against forestry, especially against clear cutting and all that. Another thing they really spoke against is when snowmobile trails were proposed into the area. There was strong opposition from the trappers. Anything, I guess, that does a bit of damage to the land (ID55, male, adult).

In the central community, an Elder described his feelings about opening the community to cultural tourism: "you cannot sell something like culture ... because you're going to destroy something, you're going to destroy the red people" (ID12, male, Elder). This same Elder is also aware, however, of the multiple viewpoints in the community, and the need to negotiate between them:

We're going to sit together and say, well, all right, during that time that we said we will only be the people that lived off the land, there are a lot of things that happened since then. You know what I mean? We're in the computer age here! And our own people went to school and they are very smart people, and they want the things that are out there.

Disagreement on how, if at all, to develop resources is also compounded by competition for financial resources. Elias (1995, p. 13) maintains this competition produces widening social gaps between those who earn wages and those who do not; the end product of this competition is tension between those who want to use resources to create wage employment and those who do not reap the fruits of such resource use.

\section{CONCLUSIONS AND IMPLICATIONS}

This paper examined the role of social networks in both overcoming and exacerbating challenges to entrepreneurship in Aboriginal communities. The paper focused on bonding relationships, the building blocks for relationships with broader networks of people. The findings illustrate how strong ties are useful in the daily operation of a business, as a marketing tool (spreading the word about a new place), and as a support group for individuals who are looking to upgrade their skills to meet the challenges of entrepreneurship. The data also 
show, however, that networks can worsen some of these challenges or undermine the process of business development: tensions between network members can reduce the size of an available market. Tensions among community members may also revolve around the direction that economic development is taking.

The findings expand on current research on the costs and benefits of social networks in business development (e.g., Portes \& Landolt 1996; 2000; Granovetter, 1995b), showing that bonding networks have an important role not only as suppliers of capital, knowledge, and assistance, but also as important consumers of products and as a support network for skill upgrading. Social networks also provide the context, the norms and values, in which a business is developed.

The discussion above also highlighted the key role that location plays in access to physical, financial, and human capital, as well as to markets. Although this paper focuses on remote Aboriginal communities, these places share many of the geographical barriers with non-Aboriginal people living in rural communities: drawing on Rosenfeld (1991) and on Rosenfeld, Shapira, and Williams (1992), Gertler et al. (1993) assert, for example, that in non-metropolitan areas, the shortage of labor skill, difficult access to information, service, and assistance, distance to markets, and difficult access to capital are significant disadvantages for the development of businesses and entrepreneurial networks (p. 61-62).

\section{Implications for Policy Makers and Entrepreneurs}

The findings and analyses presented here have several possible implications for policy makers, practitioners, and entrepreneurs. First, governments support local agencies that administer grant and loan programs to help Aboriginal business people access capital and material resources. Information about these programs trickles through bonding networks (word of mouth between extended family and friends). Consequently, policy makers must ensure that representatives of as many such groups will be informed about programs and will be involved in the decision making process of fund allocation. Such an inclusive process can be written into policy guidelines; outreach programs can be developed to this end as well.

Second, the findings show the reluctance of entrepreneurs to leave their support networks to seek business training. Skill upgrading, however, is important for the success of a business (and in turn for loan repayment). Policy makers must therefore develop distance learning training programs. For distance and electronic learning to succeed, it is crucial to provide a reliable Internet infrastructure that would allow entrepreneurs to study online while staying in their home communities.

Third, in planning business development programs, policy makers must consider the make-up of local community networks, and the tensions and alliances implicit in them. Both policy makers and entrepreneurs must be aware of the 
importance of these networks as a potential market. By requesting that aspiring entrepreneurs provide an elaborate marketing plan, policy makers can help business people understand their reliance on the local community and the possible obstacles to gaining the trust of that market. Since local markets seem to make consumer choices not only according to product quality and price but also according to personal animosities and relationships, business people should consider developing products that will cater to extra-local markets (e.g., businesses that rely on tourism or on products sold online). Policy makers can also provide funds for marketing campaigns that reach regional and national markets.

\section{Social Capital and Entrepreneurship: Future Research}

Several aspects of the analysis presented above call for further research. First, throughout the paper, I use the term bonding relationships and contrast it with other levels of social capital (bridging and linking). In the context of small, rural communities, however, these terms are often insufficient or inadequate. For example, using this framework, we refer to ties among community members as bonding ties. One can argue, however, that individuals outside one's family or those who do not live in immediate physical proximity are not part of one's bonding networks, since they are not involved in daily exchanges of support or goods. The weak/strong dichotomy fails to account for the unique association among people living in a somewhat isolated small geographic space, such as a First Nation community- or a small rural town. In the case study communities, individuals knew the exact whereabouts and address of people who were loosely tied to them. Moreover, some individuals described a reluctance to participate in community programs (such as Alcoholics Anonymous) because of lack of anonymity, or the knowledge that the entire community would be privy to their problems. Consequently, there is need for a theoretical framework that is more sensitive to geographic scales.

Second, the literature on the downsides of social capital tends to focus on the problems arising from bonding relationships, but often ignores the potential of external networks, e.g., policy makers and NGOs, to be harmful. I therefore suggest that beyond looking at the strength of weak ties (Granovetter, 1973) and the weakness of strong ties (Grabher, 1993), we must examine the weakness of weak ties; this is particularly true in the developing community context, where all too often external networks intervene with local ones, with no regard for local cultures and institutions.

Third, further analysis into relationships with external networks should address questions of power. The ability of social networks to reproduce power relations within local networks has been tackled recently (by Gertler, 2003; Rankin, 2002; and Schafft \& Brown, 2002); extending this discussion, it would be valuable to understand the power of regional, provincial, and national networks in shaping local economic development priorities and local decision making processes. Following from that, there is a need to examine whether the current public support 
for entrepreneurship is indeed the appropriate direction for Aboriginal economic development, given the paramount challenges facing small businesses in remote rural communities. Consequently, it may be useful to explore whether the regional organizations responsible for disseminating the government programs provide a forum in which community members participate in a meaningful discussion about the direction their community is taking, or whether these organizations are only a tool to carry out policies designed elsewhere.

\section{NOTES}

1. Throughout the paper I use the terms 'Aboriginal,' 'First Nations' and 'Native' interchangeably to refer to the indigenous populations of North America. I am well aware, however, that these terms obscure the distinctiveness of these populations (Royal Commission on Aboriginal Peoples [RCAP], 1996a, p. 11), as they encompass groups that differ in their political, legal, linguistic and cultural history.-

Other terms I use include 'band,' 'registered Indians' and 'reserve', which are legal terms from the Indian Act of Canada: A band is a group of First Nation people for whom lands have been set apart and for whom money is held in trust by the Crown. A Registered Indian is a person who is listed on the federal Indian Register. A reserve is land set apart and designated as a reserve for the use and occupancy of an Indian group or band. (Department of Indian Affairs and Northern Development [DIAND], 2002).

2. This definition is a synthesis of previous conceptualizations made by Bourdieu (1986), Coleman (1988), Putnam et al. (1993), Putnam (1995), Grootaert (1998), Woolcock (1998), Gertler (2000), Schuller et al. (2000) and Maskell (2000).

3. For the purposes of this study, I found the following thematic groupings of the literature on social capital and community and economic development especially useful: 1) Social capital, social networks and poverty alleviation (see, e.g., Bebbington, 1997; Bebbington \& Perreault, 1999; Daniere \& Takahashi, 2000; Edwards, 1999; Evans, 1996; Grootaert \& van Bastelaer, 2001; Isham, 2000; Krishna \& Shrader, 1999; Narayan, 1999; Uehara, 1990; Woolcock, 1998, 2000; Woolcock \& Narayan, 2000) 2) Ethnic entrepreneurs and ethnic economies (For summary and examples see Li, 1998; Light \& Bonacich, 1988; Light \& Karageorgis, 1994; Portes \& Sensenbrenner, 1993; Woolcock, 1998: 204n116) and 3) Firms and industrial regions (Clark, Feldman, \& Gertler, 2000; Cohen \& Fields, 1999; Cooke \& Morgan, 1993; Dicken, 2000; Gertler, 1993, 1995, 1997; Gertler \& Wolfe, 2002; Granovetter, 1995a; Ibarra, 1997; Maskell, 2000; Porter, 1998; Putnam et al., 1993b; Storper, 1997).

4. Both the Youth and Elder categories are the ones used by local people as well as funding agencies.

5. Individuals who are not office holders or business persons.

6. I would like to acknowledge the help of Cameron Brown, Ted Chamberlin, Andrew Chapeskie, Lynne Davis, Rick Glazier, Wally McKay, Ross Mayer, Roger Obonsawin, Karen Rice, Wendy Russell, Graham White, and Harvey Yesno.

7. The decision which question to include for each stakeholder depended on assumptions about knowledge in a specific area, and on time constraints.

\section{REFERENCES}

Abadian, S. 1999. From Wasteland to Homeland: Trauma and the Renewal of Indigenous Peoples and Their Communities. Unpublished Ph.D. Dissertation, Harvard University, Cambridge.

Adler, P. S. \& S. Kwon. 1999. Social Capital: The Good, the Bad and the Ugly. The World Bank: Papers in Progress. http://poverty.worldbank.org/files/4181_adler.pdf. Retrieved on December 6, 2004

Barnes, T. J. \& M.S. Gertler (eds.). 1999. The New Industrial Geography: Regions, Regulations and Institutions. London; New York: Routledge.

Bebbington, A. 1997. Social capital and rural intensification: Local organizations and islands of sustainability in the rural Andes. The Geographical Journal 163(2) 189-197. 
Bebbington, A. \& T. Perreault. 1999. Social capital, development and access to resources in highland Ecuador. Economic Geography 75(4): 395-411.

Bourdieu, P. 1986. The forms of capital. Pp. 241-258 in J. G. Richardson (ed.), Handbook of Theory and Research for the Sociology of Education. Westport, Connecticut: Greenwood Press.

Briggs, X. 1998. Brown kids in white suburbs: Housing mobility and the many faces of social capital. Housing Policy Debate 9(1): 177-221.

Caldwell, D. \& P. Hunt. 1998. Aboriginal Businesses: Characteristics and Strategies for Growth. Ottawa: Industry Canada.

Champagne, D. 1992. Economic culture, institutional order, and sustained market enterprises: Comparisons of historical and contemporary American Indian cases. Pp. 195-211 in T. L. Anderson (ed.), Property Rights and Indian Economies. Savage, Maryland: Rowman \& Littlefield.

Clark, G. L., M. P. Feldman \& M. S. Gertler. 2000. The Oxford Handbook of Economic Geography. Oxford, England ; New York: Oxford University Press.

Cohen, S. S. \& G. Fields. 1999. Social capital and capital gains in Silicon Valley. California Management Review 41(2): 108-130.

Coleman, J. S. 1988. Social capital in the creation of human capital. American Journal of Sociology 94(Supplement): S95-S120.

Collier, P. 1998. Social Capital and Poverty. Washington D.C.: World Bank

Cooke, P. \& K. Morgan. 1993. The network paradigm: New departures in corporate and regional development. Environment and Planning D: Society and Space 11(5): 543-564.

Cornell, S. E. \& J. P. Kalt. 1991. Where's the Glue? Institutional Bases of American Indian Economic Development. Cambridge, MA: Harvard Project on American Indian Economic Development. http://www.ksg.harvard.edu/prg/kalt/glue.htm. Retrieved on December 6, 2004.

Cornell, S. E. \& J. P. Kalt (eds). 1992. What can Tribes do? Strategies and Institutions in American Indian Economic Development. Los Angeles: American Indian Studies Center, University of California Los Angeles.

Daniere, A. \& L. M. Takahashi. 2000. Social capital and environmental management: Culture, perceptions and action among slum dwellers in Bangkok. Paper presented at the 21st Annual Conference on Economic Issues: The Role of Social Capital in Determining Well-Being: Implications for the Teaching and Practice of Development and Environmental Economics. Department of Economics, Middlebury College, Middlebury.

de Haan, A. \& S. Maxwell. 1998. Poverty and social exclusion in north and south. IDS Bulletin 29(1): $1-9$.

Department of Indian and Northern Affairs Canada. 2002. Frequently asked Questions About Aboriginal Peoples. http://www.ainc-inac.gc.ca/pr/info/info125 e.html. Retrieved on December 6, 2004.

Dicken, P. 2000. Places and flows: situating international investment. Pp. 275-591 in G. L. Clark, M. P. Feldman \& M. S. Gertler (eds.), The Oxford Handbook of Economic Geography. Oxford, England; New York: Oxford University Press.

Edwards, B. \& M. W. Foley. 1997. Social capital and the political economy of our discontent. American Behavioral Scientist 40(5): 669-678.

Edwards, M. 1999. Enthusiasts, Tacticians and Sceptics: The World Bank, Civil Society and 
Social Capital. http://poverty.worldbank.org/files/4608_edwards.pdf. Retrieved on December 6, 2004.

Elias, P. D. 1995. Northern Aboriginal Communities: Economies and Development. North York, Ont.: Captus University Publications.

Erickson, B. H. 1998. Social Capital and its Profits, Local and Global. Paper presented at the Sunbelt XVIII and 5th European International Conference, Sitges, Spain.

Evans, M. 1998. Behind the rhetoric: The institutional basis of social exclusion and poverty. IDS Bulletin 29(1): 42-49.

Evans, P. 1996. Government action, social capital and development: Reviewing the evidence on synergy. World Development 24(6): 1119-1132.

Flora, J. L., J. Sharp, C. Flora \& B. Newlon. 1997. Entrepreneurial social infrastructure and locally initiated economic development in the nonmetropolitan United States. The Sociological Quarterly 38(4): 923-645.

Fukuyama, F. 1996. Trust: The Social Virtues and the Creation of Prosperity. London: Penguin Books.

Gagnè, M.-A. 1994. A Nation Within a Nation: Dependency and the Cree. Montreal: Black Rose Books.

Gaventa, J. 1998. Poverty, participation and social exclusion in North and South. IDS Bulletin 29(1): 50-57.

Gertler, M. S. 1993. Implementing advanced manufacturing technologies in mature industrial regions: Towards a social model of technology production. Regional Studies 27(7): $665-680$.

Gertler, M. S. 1995. "Being there": Proximity, organization, and culture in the development and adoption of advanced manufacturing technologies. Economic Geography 71(1): 1-26.

Gertler, M. S. 1997. The invention of regional culture. Pp. 47-58 in R. Lee \& J. Wills (eds.), Geographies of Economies (4th ed.). London: Edward Arnold.

Gertler, M. S. 2000. Social capital. In R. Johnston, D. Gregory, G. Pratt, D. Smith \& M. Watt (eds.), The Dictionary of Human Geography (4th ed.). Cambridge, MA: Blackwell Publishers.

Gertler, M. S. 2003. A cultural economic geography of production. Pp 131-146 in K. Anderson, M. Domosh, S. Pile \& N. J. Thrift (eds.), Handbook of Cultural Geography. London: Sage Publications.

Gertler, M. S. and Y. M. Levitte. Forthcoming. Local nodes in global networks: The geography of knowledge flows in biotechnology innovation. Regional Studies

Gertler, M. S., T. D. Rutherford, S. DiGiovanna, D. Kershaw \& J. Sells. 1993. Regional Industrial Networks and the Role of Labour: Europe, North America, and Northern Ontario, part 1 report. Toronto: Prepared for the United Steelworkers of America, Employment and Immigration Canada, and the Ontario Ministry of Labour.

Gertler, M. S. \& D. A. Wolfe. 2002. Innovation and Social Learning: Institutional Adaptation in an era of Technological Change. Basingstoke: Palgrave.

Gittell, R. J. \& A. Vidal. 1998. Community Organizing: Building Social Capital as a Development Strategy. Thousand Oaks, Calif.: Sage Publications.

Grabher, G. 1993. The Weakness of strong ties: the lock-in of regional development in the Ruhr area. Pp. 227-252 in G. Grabher (ed.), The Embedded Firm: On the Socioeconomics of Industrial Networks. London; New York: Routledge. 
Granovetter, M. S. 1973. The strength of weak ties. American Journal of Sociology 78(6): 13601380 .

Granovetter, M. S. 1985. Economic action and social structure: The problem of embeddedness. American Journal of Sociology 91(2): 481-510.

Granovetter, M. S. 1995a. Getting a Job: A Study of Contacts and Careers. Cambridge, MA: Harvard University Press.

Granovetter, M. S. 1995b. The economic sociology of firms and entrepreneurs. pp. 128-165 in A. Portes (ed.), The Economic Sociology of Immigration: Essays on Networks, Ethnicity, and Entrepreneurship. New York: Russell Sage Foundation.

Grootaert, C. 1998. Social Capital: The Missing Link. Washington D. C.: The World Bank.

Grootaert, C. \& T. van Bastelaer. 2001. —Washington D.C: The World Bank.

Hawthorn, H. B, H. A. C Cairns, S. M. Jamieson \& K. Lysyk. 1966. A Survey of the Contemporary Indians of Canada: A report on Economic, Political, Educational Needs and Policies Volume 1. Ottawa: Indian Affairs Branch.

Ibarra, H. 1997. Paving an alternative route: Gender differences in managerial networks. Social Psychology Quarterly 60(1): 91-102.

Isham, J. 2000. Can Investments in Social Capital Improve Well-being in Fishing Communities? A Theoretical Perspective for Assessing the Policy Options. Paper presented at the 10th Biennial Meeting of the International Institute of Fisheries Economics and Trade.

Krishna, A. \& E. Shrader. 1999. Social Capital Assessment Tool. Paper presented at the Conference on Social Capital and Poverty Reduction. Washington, D.C.: The World Bank.

Leyshon, A. \& N. J. Thrift. 1997. Money/Space: Geographies of Monetary Transformation. London; New York: Routledge.

Li, W. 1998. Anatomy of a new ethnic settlement: The Chinese ethnoburb in Los Angeles. Urban Studies 35(2): 479-501.

Light, I. \& E. Bonacich. 1988. nImmigrant Entrepreneurs: Koreans in Los Angeles 1965-1982. Berkeley: University of California Press.

Light, I. \& S. Karageorgis. 1994. The ethnic economy. Pp. 647-671 in N. J. Smelser \& R. Swedberg (eds.), nThe Handbook of Economic Sociology . New York: Princeton University Press; Russell Sage Foundation.

Light, I. \& C. Rosenstein. 1995. Expanding the interaction theory of entrepreneurship. Pp. 166212 in A. Portes (ed.), The Economic Sociology of Immigration: Essays on Networks, Ethnicity, and Entrepreneurship. New York: Russell Sage Foundation.

Lin, N. 1998. Social networks and status attainment. Annual Review of Sociology 25: 467-488.

Martin, R. 1994. Stateless monies, global financial integration, and national economic autonomy: the end of geography? Pp. 253-278 in S. Corbridge, R. Martin \& N. J. Thrift (eds.), Money, Power, and Space. Oxford, England; Cambridge, Mass.: Blackwell.

Morgan, K. 1997. The learning region: Institutions, innovation and regional renewal. Regional Studies 31: 491-503.

Maskell, P. 2000. Social capital, innovation, and competitiveness. Pp. 111-123 in S. Baron, J. Field \& T. Schuller (eds.), Social Capital: Critical Perspectives. Oxford; New York: Oxford University Press.

Narayan, D. 1999. Bonds and bridges: Social capital and poverty. Washington, DC: The World Bank. http://www.worldbank.org/html/dec/Publications/Workpapers/wps2000series/ wps2167/wps2167.pdf. Retrieved on December 6, 2004. 
Native Investment and Trade Association (NITA). 1998. The Road Less Traveled: Aboriginal Entrepreneurs Building Economic Independence in the 1990s. Vancouver: Native Investment and Trade Association.

Newton, K. 1997. Social capital and democracy. American Behavioral Scientist 40 (5): 575-586.

Polanyi, K. 1957. The Great Transformation. Boston: Beacon Press.

Porter, M. E. 1998. Clusters and the new economies of competition. - Harvard Business Review, November-December.

Portes, A. 1998. Social capital: Its origins and applications in contemporary sociology. Annual Review of Sociology 24(1): 1-24.

Portes, A. \& P. Landolt. 1996. The downside of social capital. The American Prospect 26(MayJune): $18-21$.

Portes, A. \& P. Landolt. 2000. Social capital: Promise and pitfalls of its role in development. Journal of Latin American Studies 32(2): 529-547.

Portes, A. \& J. Sensenbrenner. 1993. Embeddedness and immigration: Notes on the social determination of economic action. American Journal of Sociology 98(May): 13201350.

Putnam, R. D. 1993. The prosperous community. The American Prospect, 14(3). http:// www.prospect.org/print/V4/13/putnam-r.html. Retrieved on December 6, 2004.

Putnam, R. D. 1995. Bowling alone: America's declining social capital. Journal of Democracy 6(1): 65-78.

Putnam, R. D., R. Leonardi \& R. Nanetti. 1993. Making Democracy Work: Civic Traditions in Modern Italy. Princeton, N.J.: Princeton University Press.

Rankin, K. 2002. Social capital, microfinance, and the politics of development. Feminist Economics 8(1): 1-24.

Rosenfeld, S. 1991. Rural perspectives: Linking networks and economic development. The Entrepreneurial Economy Review 9(1): 28-31.

Rosenfeld, S., P. Shapira \& J. T. Williams. 1992. Smart Firms in Small Towns. Washington, D.C.: The Aspen Institute.

Royal Commission on Aboriginal Peoples. 1996a. Volume 1: Looking Forward, Looking Back. Ottawa: Royal Commission on Aboriginal Peoples.

Royal Commission on Aboriginal Peoples. 1996b. Volume 3: Gathering Strength. Ottawa: Royal Commission on Aboriginal Peoples.

Royal Commission on Aboriginal Peoples. 1996c. Volume 5: A Twenty Year Commitment. Ottawa: Royal Commission on Aboriginal Peoples.

Royal Commission on Aboriginal Peoples. 1996d. Volume 2: Restructuring the Relationship. Ottawa: Royal Commission on Aboriginal Peoples.

Schafft, K. A. \& D. L. Brown. 2002. Social Capital, Social Networks, and Social Power. Paper presented at the Workshop on Social Capital and Civic Involvement, Cornell University and the University of Turin, Ithaca, NY.

Schuller, T., S. Baron, S. \& J. Field. 2000. Social capital: A review and Critique. Pp. 1-38 in S. Baron, J. Field \& T. Schuller (eds.), Social Capital: Critical Perspectives . Oxford, New York: Oxford University Press.

Shkilnyk, A. M. 1985. A Poison Stronger than Love: The Destruction of an Ojibwa Community. New Haven: Yale University Press.

Simmel, G. 1971 [1908]. Exchange. Pp. 43-69 in D. N. Levin (ed.), On Individuality and Social 
Forms: Selected Writings. Chicago: University of Chicago Press.

Storper, M. 1997. Chapter 6: Regional worlds of production: Conventions of learning and innovation in the technology of France, Italy, and the United States. Pp. 134-165 in M. Storper (ed), The Regional World: Territorial Development in a Global Economy. New York: Guilford Press.

Swedberg, R. 2000. Entrepreneurship: the Social Science View. New York: Oxford University Press.

Uehara, E. 1990. Dual exchange theory, social networks, and informal social support. American Journal of Sociology, 96: 521-557.

Waldinger, R. 1986. Immigrant enterprise: A critique and reformulation. Theory and Society 15(1/2): 249-285.

Warry, W. 1998. Unfinished Dreams: Community Healing and the Reality of Aboriginal SelfGovernment. Toronto: University of Toronto Press.

Weber, M. 1969 [1920]. The Theory of Social and Economic Organization. Translated by A.M. Henderson \& T. Parsons. New York: Free Press.

Woolcock, M. 1998. Social capital and economic development: Toward a theoretical synthesis and policy framework. Theory and Society 27: 151-208.

Woolcock, M. 2000. Social Capital in Theory and Practice: Where do We Stand? Paper presented at the 21st Annual Conference on Economic Issues: The Role of Social Capital in Determining Well-Being: Implications for the Teaching and Practice of Development and Environmental Economics. Department of Economics, Middlebury College, Middlebury.

Woolcock, M. \& D. Narayan. 2000. Social capital: implications for development theory, research, and policy. The World Bank Research Observer 15(2): 225-249.

World Bank Group. 2004. Sources of Social Capital. Washington D.C.: The http:// www1.worldbank.org/prem/poverty/scapital/sources/index.htm. Retrieved on December 6, 2004.

York, G. 1990. The Dispossessed: Life and Death in Native Canada. London: Vintage U.K.

Government. Toronto: University of Toronto Press.

Weber, M. 1969 [1920]. The Theory of Social and Economic Organization. Translated by A.M. Henderson \& T. Parsons. Introduction by T. Parsons. New York: Free Press.

Woolcock, M. 1998. Social capital and economic development: Toward a theoretical synthesis and policy framework. Theory and Society 27: 151-208.

Woolcock, M. 2000. Social Capital in Theory and Practice: Where do we Stand? Paper presented at the 21st Annual Conference on Economic Issues: The Role of Social Capital in Determining Well-Being: Implications for the Teaching and Practice of Development and Environmental Economics. Department of Economics, Middlebury College, Middlebury.

Woolcock, M. \& D. Narayan. 2000. Social capital: implications for development theory, research, and policy. The World Bank Research Observer 15(2): 225-249.

World Bank Group. 2004. Sources of Social Capital. Washington D.C.: The http:// www1.worldbank.org/prem/poverty/scapital/sources/index.htm. Retrieved on December 6, 2004.

York, G. 1990. The Dispossessed: Life and Death in Native Canada. London: Vintage U.K. 